\title{
Relationship between Sexual Maturity and Serum and Testis Testosterone Concentrations in Short-finned Pilot Whales Globicephala macrorhynchus
}

\author{
Shoichi Kita, Motoi Yoshioka, and Masaaki Kashiwagi \\ Laboratory of Fish Culture, Faculty of Bioresources, Mie University, Kamihama, \\ Tsu, Mie 514-8507, Japan
}

(Received March 11, 1999)

\begin{abstract}
Testes and blood samples were collected from males of the southern form short-finned pilot whale Globicephala macrorhynchus, caught by a small-type coastal whaling and the drive fishery off the Pacific coast of Japan in order to examine relationships of serum and testis concentrations of testosterone with testis weight, diameter of seminiferous tubules and density of reproductive cells. Serum and testis concentrations of testosterone ranged from 0.27 to $22.0 \mathrm{ng} / \mathrm{m} l$ and from 14.4 to $287.1 \mathrm{ng} / \mathrm{g}$, respectively. Testis testosterone levels were more than 5 to 180 times higher than serum levels. Before the attainment of sexual maturity, both serum and testis testosterone levels were significantly correlated with testis weight and diameter of seminiferous tubules, but no significant relationship was shown after sexual maturity. There was no correlation between serum and testis concentrations of testosterone and density of reproductive cells in mature individuals.
\end{abstract}

Key words: short-finned pilot whale, testosterone, serum, testis, density of reproductive cells

Testosterone is one of the main androgens in mammals and it stimulates spermatogenesis. ${ }^{1)}$ Measurement of serum sex hormone concentration has provided new knowledge on reproductive physiology of cetaceans in recent years, ${ }^{2-4)}$ and seasonal changes in testicular activity have been discussed by the comparison of serum testosterone concentration with testis weight or sperm density. ${ }^{5-7)}$ However, few studies have been conducted on testosterone secretion dynamics and differentiation of reproductive cells in cetacean testes. A purpose of this study was to clarify the relationship between histological and endocrinological changes in cetacean testes with the progress of testis maturity. We measured serum and testis concentrations of testosterone in the short-finned pilot whale Globicephala macrorhynchus, and investigated the relationship of those concentrations with testis weight, diameter of seminiferous tubules and density of reproductive cells.

\section{Materials and Methods}

\section{Study Animals}

All samples used in the present study were collected from southern form short-finned pilot whales, caught by a small-type coastal whaling and the drive fishery off the Pacific coast of Taiji, Wakayama Prefecture, Japan in 1995 and 1996. We collected samples from 51 individuals in the small-type coastal whaling in May, June and September, 1995, and May, 1996, and from 27 individuals in the drive fishery in October, 1996. After body length of the whales was measured, both testes with epididymis and blood samples were obtained in the field as described below. All samples from the individuals captured by the small-type coastal whaling were collected under the Biological Research Program of National Research Institute of
Far Seas Fisheries, Japan, and their body length and testis weight data were provided by the Fisheries Agency of Japan.

\section{Testis Tissues}

After removal of the epididymis, each fresh testis was weighed. As Kasuya and Marsh ${ }^{8}$ found that left and right testes do not show significant difference in maturation, histological samples were collected from the central part of right testis (about $30 \mathrm{~mm} \times 30 \mathrm{~mm} \times 20 \mathrm{~mm}$ ). For 27 individuals collected in the drive fishery, tissue samples were collected from the testis but which side the testis was taken from was unknown because the fishermen had already removed the testes from the body. Histological samples were fixed in a $10 \%$ buffered formalin solution in the field. In the laboratory, histological samples were processed using standard techniques, and the slides were stained with haematoxylin-eosin. Stained histological samples were observed with a light-microscope $(200 \times)$. Tissue samples for the measurement of testosterone were also collected from the central part of the testis (about $100 \mathrm{~g}$ ), and stored at $-20^{\circ} \mathrm{C}$ until later hormonal assay.

\section{Blood Samples}

Blood samples were taken from the heart of each carcass with a $10 \mathrm{~m} l$ vacuum glass tube containing serum-separation-agent (Serapo L10, Nipro, Tokyo). After centrifugation $(3,000 \mathrm{rpm}, 15 \mathrm{~min})$ in the field, sera were stored at $-20^{\circ} \mathrm{C}$ until assay.

\section{Classification of Reproductive Status}

Sexual maturity of individual whales was classified into the following four classes according to Kasuya and $\mathrm{Marsh}^{8)}$ using the proportion of mature seminiferous tubules 
(i.e., those having spermatozoa, spermatids or spermatocytes) on the histological section;

(1) immature: 100\% immature tubules,

(2) early-maturing: less than $50 \%$ of mature tubules,

(3) late-maturing: between $50 \%$ and $100 \%$ of mature tubules,

(4) mature: 100\% mature tubules.

\section{Measurement of the Diameter of Seminiferous Tubules}

One hundred seminiferous tubules with a circular shape were selected, and each diameter was measured with a micrometer $(200 \times)$. The mean of those 100 diameters of seminiferous tubules was regarded as the mean tubule diameter of the individual.

\section{Measurement of Male Reproductive Cell Density}

Thirty seminiferous tubules with a circular shape were selected, and the number of reproductive cells ("reproductive cell" is defined here as spermatozoa, spermatids and spermatocytes) was counted in each tubule. After the area of each tubule was measured via the following manner, the density of reproductive cells was calculated as the number of cells per $1,000 \mu \mathrm{m}^{2}$. The mean density of reproductive cells for the individual was regarded as the mean of 30 densities.

For the measurement of the area of each tubule, an outline of the microscopic picture on a TV monitor was traced on an OHP transparency sheet, and the area was calculated by the computer program NIH Image Version. 1.56 (National Institute of Health, USA) after scanning of the outline image.

\section{Extraction of Testosterone from Serum and Testis Tissue}

Testosterone was extracted from the serum by the method of Asahina et al..$^{91}$ with some modifications. Namely, steroids were extracted twice using ten times the volume of diethylether from the serum. The ether was evaporated in a waterbath $\left(40^{\circ} \mathrm{C}\right)$. The dried extract was then reconstituted with an assay buffer $(0.05 \mathrm{M}$ borate buffer, $\mathrm{pH} 7.8$, containing $0.1 \% \mathrm{BSA}$ and $0.01 \%$ thimerosal) and it was stirred for one minute.

Testosterone was extracted from testis tissue by the method of Yoshioka et al. ${ }^{10)}$ with some modifications. Namely, about $0.5 \mathrm{~g}$ of thawed testis tissue was minced and homogenized (Hitachi Homogenizer HG30) in a $50 \mathrm{ml}$ centrifuge tube after $2 \mathrm{~m} l$ of borate buffer $(0.05 \mathrm{M}$ borate, $\mathrm{pH} 7.8$ ) were added. Then, $4 \mathrm{~m} /$ of diethylether were added to the centrifuge tube, and it was stirred using a vortex mixer for one minute. After centrifugation $(10,000$ $\left.\mathrm{rpm}, 15 \mathrm{~min}, 4^{\circ} \mathrm{C}\right)$, the ether layer was collected in the glass test tube $(12 \mathrm{~mm} \phi \times 75 \mathrm{~mm})$. After the second extraction $(4 \mathrm{~m} /$ ether; $30 \mathrm{sec}$ stirring; $10,000 \mathrm{rpm}, 10 \mathrm{~min})$, the ether layer was pooled in the test tube. The ether was evaporated in a waterbath $\left(40^{\circ} \mathrm{C}\right)$. Then, $1 \mathrm{~m} /$ of assay buffer was added to the dried extract, and it was stirred for one minute.

\section{EIA (Enzyme-Immunoassay)}

Serum and testis concentrations of testosterone were measured by the method of Asahina et al. ${ }^{9)}$ with some modifications. Anti-testosterone-3(E) CMO-BSA rabbit serum (FKA 102E serum, rabbit 57-2, Cosmo Bio., Tokyo), goat affinity purified antibody to rabbit IgG (Cappel Research Products, LOT\#39032), and testosterone-3(E)CMO-HRP (FKA 101, Cosmo Bio., Tokyo) were used in the EIA. The first antibody cross-reacted with $5 \alpha$-dihydrotestosterone (DHT), 4-androstenedione, androsterone, 5 -androstene- $3 \beta, 17 \beta$-diol, $5 \alpha$-androstane- $3 \alpha, 17 \beta$ diol, $5 \beta$-androstane- $3 \alpha, 17 \beta$-diol, cortisol, corticosterone at $5.8,0.8,0.18,0.05,0.04,0.05,0.01,0.01 \%$, respectively (Data provided by Cosmo). Desportes et al. ${ }^{(1)}$ reported that plasma testosterone levels were 10 to 20 times higher than $5 \alpha$-DHT levels in male long-finned pilot whales Globicephala melas with various stages of sexual maturity. Therefore, we consider total testosterone concentration plus $5.8 \%$ of the $5 \alpha$-DHT is acceptable as testosterone levels in the present study.

Fifty microliters of sample, labeled antigen and the first antibody were added into the wells of a second antibodycoated plate (Nunc Immuno Plate 439454, Nalge Nunc International, Denmark). The coating buffer and blocking solution were $0.05 \mathrm{M}$ carbonate buffer $\mathrm{pH} 8.4$, containing $0.05 \% \mathrm{NaN}_{3}$ and $0.05 \mathrm{M}$ PBS containing $0.1 \% \mathrm{BSA}, 3 \%$ sucrose, and $0.005 \%$ thimerosal, respectively. The plate was incubated at $4^{\circ} \mathrm{C}$ for $12 \mathrm{~h}$, then drained and washed eight times with a washing solution $(200 \mu l ; 0.85 \% \mathrm{NaCl})$. Then, $150 \mu$ l of substrate solution $(0.2 \mathrm{M}$ citrate buffer, $\mathrm{pH} 4.5$, containing $0.01 \% \mathrm{H}_{2} \mathrm{O}_{2}$, with $0.5 \% \quad o$-phenylenediamine added immediately before use) was added to each well, and the plate was incubated at $20^{\circ} \mathrm{C}$ for $20 \mathrm{~min}$. Color development was stopped by adding $50 \mu \mathrm{l}$ of stopping solution $\left(6 \mathrm{~N} \mathrm{H}_{2} \mathrm{SO}_{4}\right)$ to each well. Absorbance of each well was measured at $490 \mathrm{~nm}$ with a microplate leader (BIORAD Model 3550).

\section{Results}

\section{Validation of the Assay}

Figure 1 shows competition curves of the testosterone standard and of the serial dilution of serum and of extracts from testes. The relationship between the standard curve of testosterone and the competition curves of serum and extracts from testes showed parallelism at about $50 \%$ binding (Parallel line test, $p>0.05$ ). Recovery was examined by adding known amounts of testosterone $(312,625,1250$, $2,500,5,000 \mathrm{pg} / \mathrm{ml}$ ) to serum and extracts from testes (Fig. 2). The regression lines were obtained $y=0.8835 x+92.588 \quad(r=0.9951) \quad$ for serum and $y=1.1002 x+188.5(r=0.9869)$ for extracts from testes, respectively. Extraction rate was calculated as $66.8 \pm 7.68 \%$ (mean $\pm \mathrm{SD} ; n=4$ ), when $200 \mathrm{ng} /$ tube of testosterone was added during homogenization of testis tissue. Although the extraction rate for testis tissues was a little lower than that for serum (more than $90 \%$, Kobayashi et al. ${ }^{12)}$ ), testosterone concentrations shown below are not corrected with these extraction rates. Intra- and inter-assay coefficients of variation were $3.6 \%$ and $10.4 \%$ (serum, $n=5$ ) and $7.3 \%$ and $9.3 \%$ (testes, $n=5$ ), respectively.

\section{Testosterone Concentration}

Table 1 shows serum and testis concentrations of testosterone in the short-finned pilot whales used in the present study. Serum concentration ranged from 0.27 to $22.0 \mathrm{ng} / \mathrm{m} /$, and testis concentration ranged from 14.4 to 

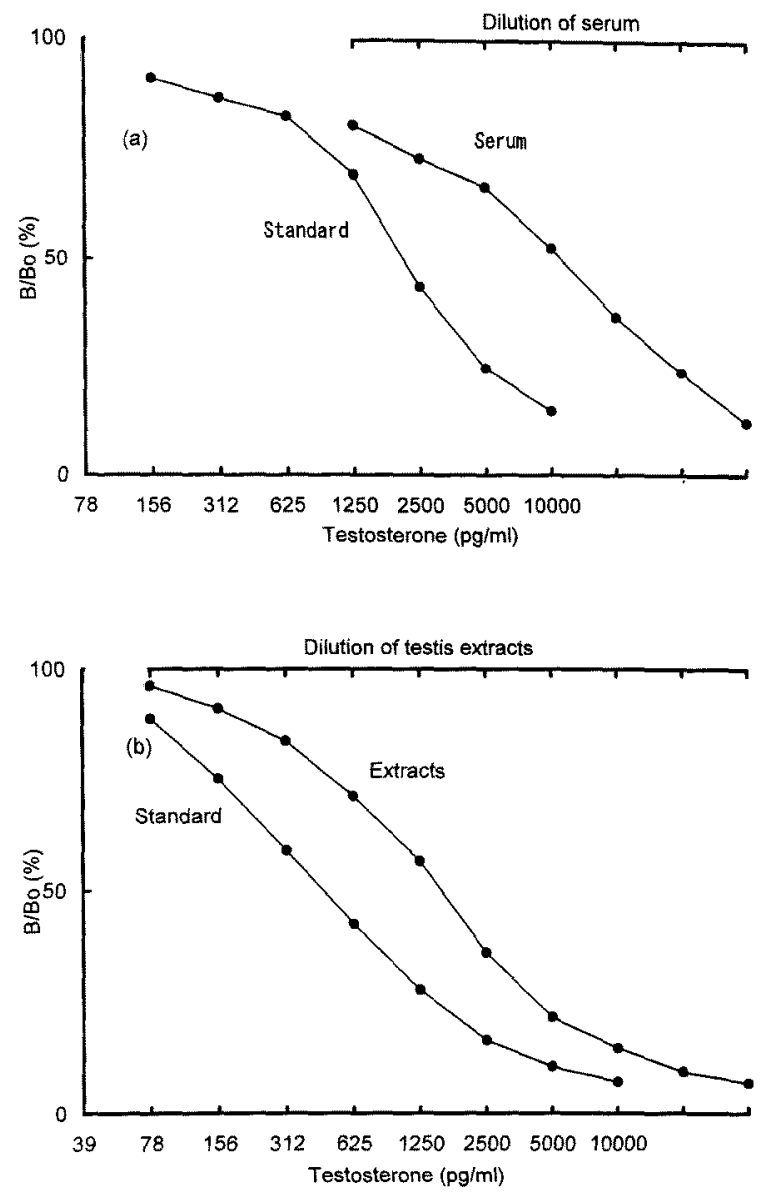

Fig. 1. Competition curves of the testosterone standard and of several dilutions of serum (a) and extracts from testis (b).

Each point represents the average of a triplicate determination.

$287.1 \mathrm{ng} / \mathrm{g}$. Lowest concentration of both serum and testis levels was detected in immature animals while the highest values were in the mature individuals. Serum and testis concentrations of testosterone in mature pilot whales were also significantly higher than in immature animals (MannWhitney's $U$-test, $p<0.05$ ).

Figure 3 shows the relationship between serum and testis concentrations of testosterone. Serum testosterone concentration $(x, \mathrm{ng} / \mathrm{m} l)$ was significantly correlated with testis testosterone concentration $(y, \mathrm{ng} / \mathrm{g})$ in the range less than $5 \mathrm{ng} / \mathrm{m} l(y=33.926 x+33.079, r=0.62, p<0.05)$, while levels greater than or equal to $5 \mathrm{ng} / \mathrm{m} l$ were not significantly correlated $(r=0.09, p>0.05)$. Testis testosterone levels were more than 5 to 180 times higher than serum levels. As we had samples from spring and fall for mature individuals, we compared testosterone concentration between these two seasons (Fig. 4). Serum concentration was not significantly different between spring and fall (Mann-Whitney's $U$-test, $p>0.05$ ), but the testis concentration from spring samples was significantly higher than those of fall (Mann-Whitney's $U$-test, $p<0.05$ ).

\section{Testosterone Concentration and Sexual Maturity}

Relationships of the serum concentration of testosterone with testis weight and the diameter of seminiferous
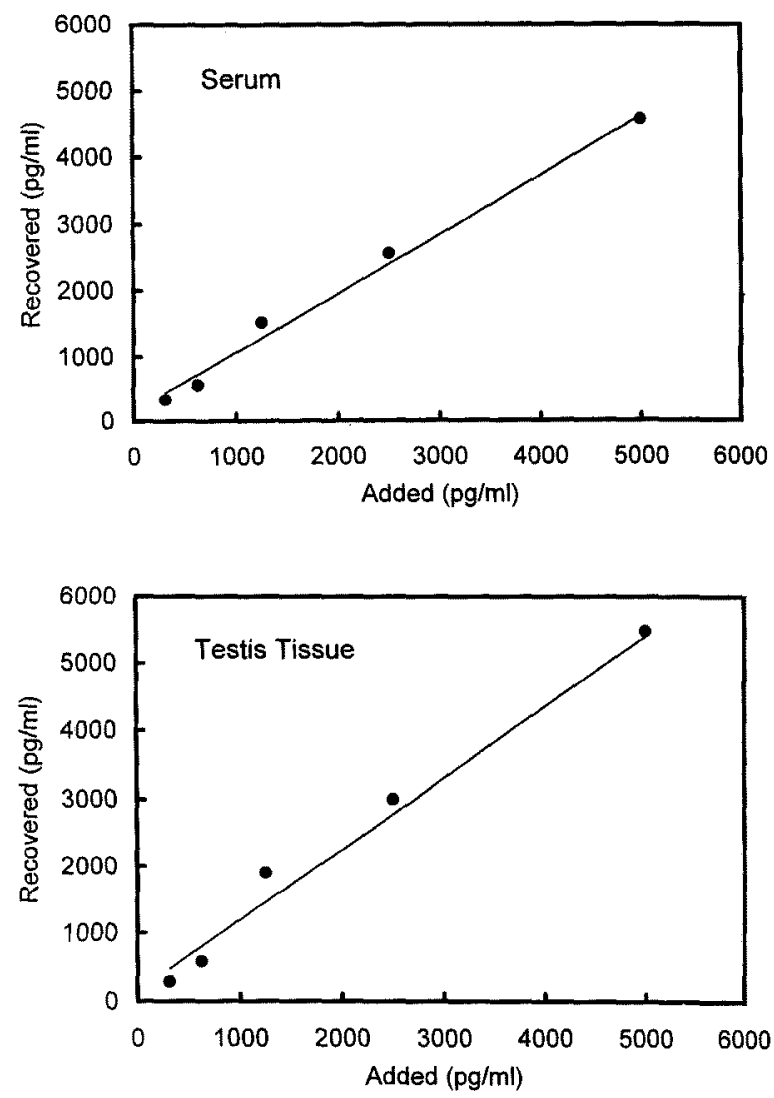

Fig. 2. Recoveries of testosterone added to serum and extracts from testis.

Each point represents the average of triplicate determinations. For the solid lines see text.

Table 1. Serum and testis concentrations of testosterone in shortfinned pilot whales

\begin{tabular}{lcc}
\hline Reproductive status & Serum $(\mathrm{ng} / \mathrm{m} l)$ & Testis tissue $(\mathrm{ng} / \mathrm{g})$ \\
\hline Immature & $0.48 \pm 0.44^{* 1}(10)^{* 2}$ & $51.23 \pm 11.15(12)$ \\
& $(0.27-0.73)^{* 3}$ & $(14.4-154.9)$ \\
Early-maturing & $1.46 \pm 0.64(2)$ & $122.22 \pm 40.82(3)$ \\
& $(0.82-2.09)$ & $(42.0-171.6)$ \\
Late-maturing & $2.36 \pm 0.38(5)$ & $157.98 \pm 21.93(6)$ \\
& $(1.48-3.51)$ & $(114.8-264.2)$ \\
Mature & $5.43 \pm 1.18(19)$ & $128.64 \pm 28.73(56)$ \\
& $(1.54-22.0)$ & $(33.0-287.1)$ \\
\hline
\end{tabular}

${ }^{*_{1}}$ mean $\pm S . E . M .,{ }^{*_{2}}$ sample size, ${ }^{*_{3}}$ range.

tubules are shown in Fig. 5. Before the attainment of sexual maturity, serum concentration $(y, \mathrm{ng} / \mathrm{m} l)$ was significantly correlated with testis weight $(x, g)$ and the diameter of seminiferous tubules $(x, \mu \mathrm{m})$, respectively. The relationships are shown by the following regression equations:

Testis weight:

$$
y=0.0062 x+0.3518(10<x<480, r=0.899, p<0.05)
$$

Diameter of seminiferous tubules:

$$
y=0.0275 x-0.5861(32<x<123, r=0.865, p<0.05) \text {. }
$$




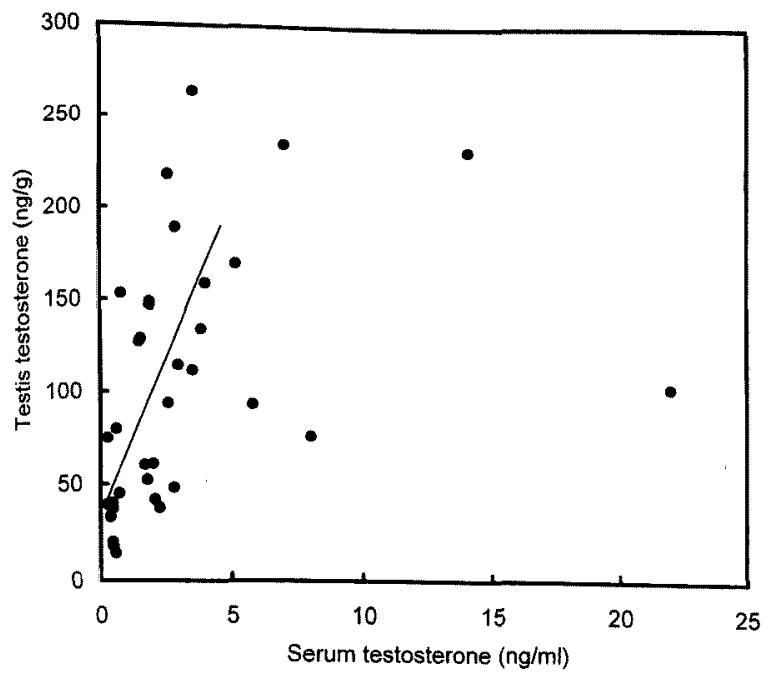

Fig. 3. Relationship between serum and testis concentrations of testosterone in the short-finned pilot whales.

For the solid line see text.

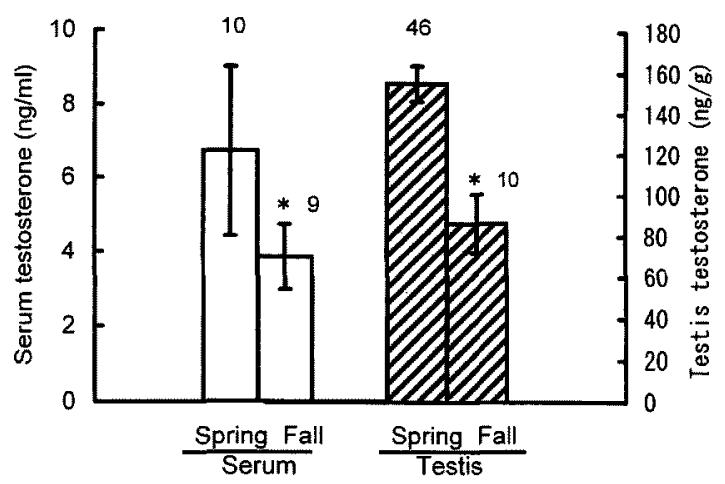

Fig. 4. Comparison of concentration of serum and testis testosterone between two seasons.

Vertical bars indicate S.E.M., with sample size given above each bar. Asterisk indicates significant difference detected by Mann-Whitney's $U$-test $(p<0.05)$.

After sexual maturity, serum testosterone concentration varied widely irrespective of testis weight and the diameter of seminiferous tubules.

Figure 6 shows relationships between the testis concentration of testosterone $(y, \mathrm{ng} / \mathrm{g})$ with testis weight $(x, \mathrm{~g})$ and the diameter of seminiferous tubules $(x, \mu \mathrm{m})$. Both relationships were similar for serum concentration (Fig. 5). The regression lines are shown as follows:

Testis weight:

$$
y=0.3753 x+40.848(10<x<480, r=0.775, p<0.05)
$$

Diameter of seminiferous tubules:

$$
y=1.45154 x-1.6119(32<x<123, r=0.723, p<0.05) \text {. }
$$

The density of reproductive cells in mature individuals did not show significant correlation with either serum or testis testosterone levels (Fig. 7).
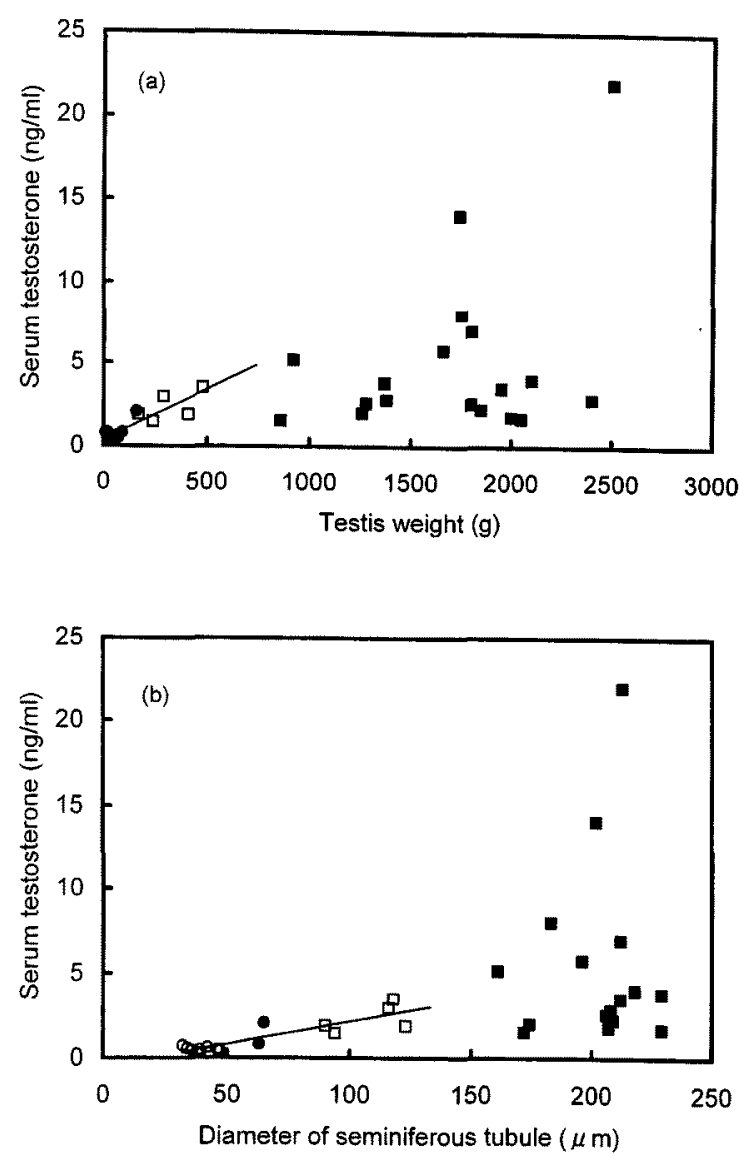

Fig. 5. Relationship between serum concentration of testosterone and testis weight (a) and the diameter of seminiferous tubules (b).

Open circle: immature; closed circle: early-maturing; open square: late-maturing; closed square: mature. For the solid lines see text.

\section{Discussion}

In a recent study on the relative species, long-finned pilot whale, it is reported that a testis weight of $2 \mathrm{~kg}$ and greater in mature individuals was significantly correlated with serum testosterone concentration. ${ }^{11)}$ In the present study, after the short-finned pilot whale attained sexual maturity, testis weight was not significantly correlated with either serum or testis testosterone concentration, which is a different result than in long-finned pilot whales. Although serum testosterone levels were significantly correlated with testis weight in the long-finned pilot whale, ${ }^{11)}$ the plots of the levels and weight were widely scattered on the graph by Desportes et al., ${ }^{11)}$ and showed a similar pattern to our results. Therefore, we consider that there is not a large difference in the relationships between serum testosterone levels and testis weight between the two species. In the short-finned pilot whale, serum testosterone concentration was less than $1 \mathrm{ng} / \mathrm{ml}$ in immature individuals, and fluctuated between 1.54 and $22 \mathrm{ng} / \mathrm{m} l$ in mature animals. This is similar to the values reported in the longfinned pilot whale. ${ }^{11}$ Seasonal fluctuation of serum testosterone concentration in mature individuals has been documented in the captive bottlenose dolphin Tursiops 

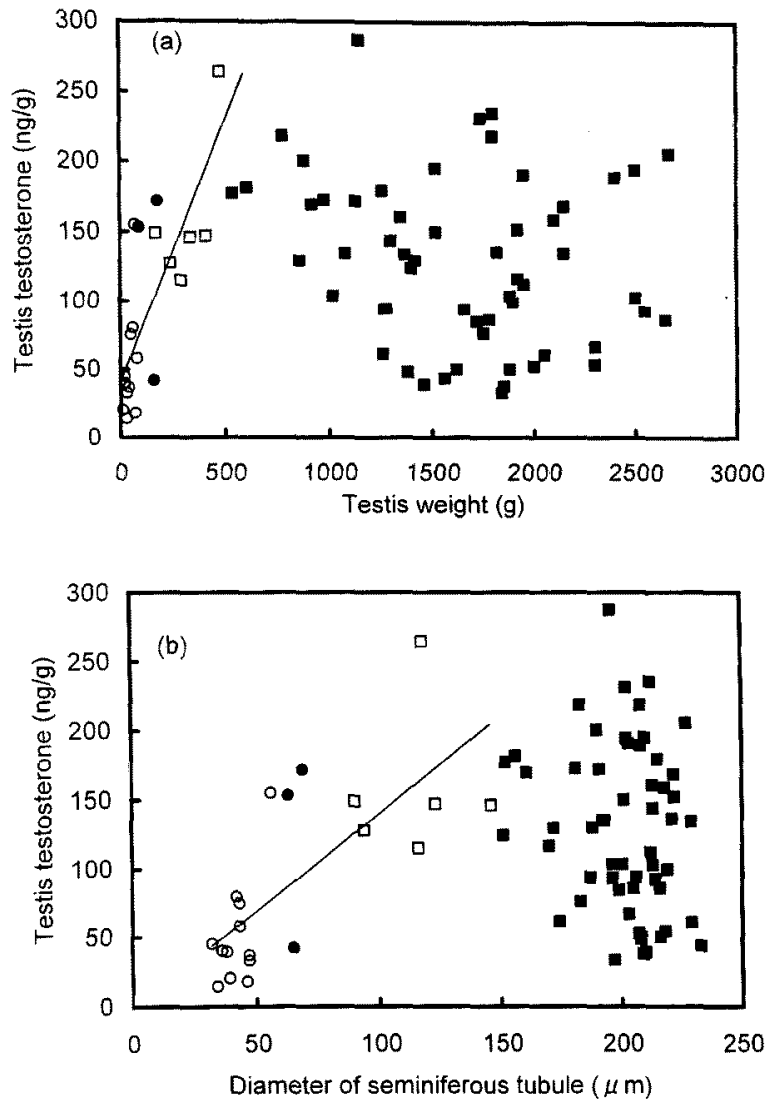

Fig. 6. Relationship between testis concentration of testosterone and testis weight (a) and the diameter of seminiferous tubules (b).

Symbols are the same as in Fig. 5. For the solid lines see text.

truncatus $^{5,13)}$ and the spinner dolphin Stenella longirostris. ${ }^{6)}$ The fluctuation of testosterone in mature individuals of the short-finned pilot whale may be partially due to seasonal change.

The present study evaluated testis testosterone concentration at cetaceans in wild for the first time. In the mature male rat, it is reported that testis fluid testosterone concentration was 20 to 30 times higher than the serum concentration. ${ }^{14)}$ Testis testosterone concentration was a few to several tens of times higher than serum concentration in shortfinned pilot whales. Relationships of testis concentration with testis weight and the diameter of seminiferous tubules were similar to those of serum concentration. Testis concentration in spring was significantly higher than that in fall (Fig. 4), and this was in agreement with Kasuya and $\mathrm{Marsh}^{8)}$ who reported that the peak of the reproductive season of short-finned pilot whales was from March to May in the population off southern Japan. From the wide variation in the testicular histology of mature individuals as Kasuya and Marsh $^{8)}$ suggested, it is possible that the time of spermatogenesis was different among individuals. Kasuya et al.$^{15}$ reported that all schools contain several mature males that produce spermatozoa continuously and the presence of uterine sperm was not correlated with mating season, age or reproductive status of mature females. In the present study, both the density of reproductive cells and testosterone levels largely fluctuated even in individ-
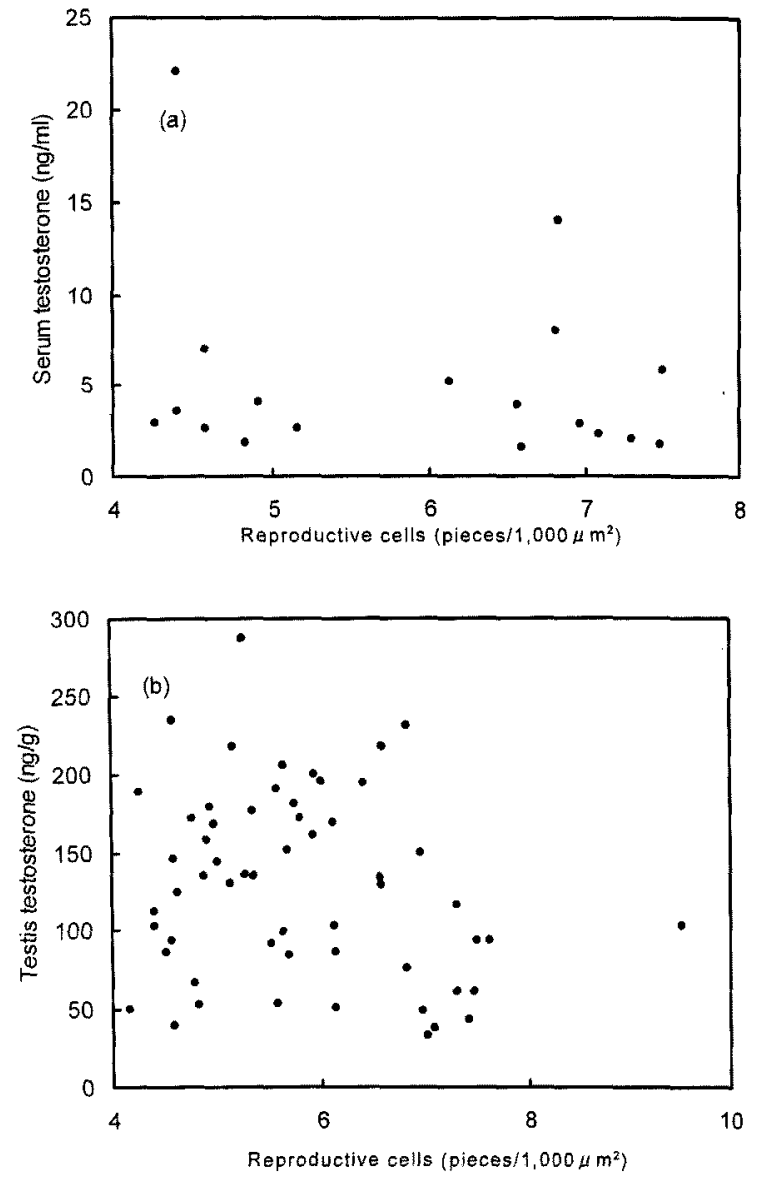

Fig. 7. Relationship between serum (a) and testis (b) concentrations of testosterone and the density of male reproductive cells.

uals that were caught in the same season. Namely, spermatogenesis did not synchronize in mature individuals, which also supports the result of Kasuya and Marsh. ${ }^{8)}$

In conclusion, both serum and testis testosterone showed positive correlations with testis weight and the diameter of seminiferous tubules before animals attain sexual maturity, but no significant relationship was observed after maturity. Testosterone concentration and the density of reproductive cells in mature individuals were not correlated, either. That is, testosterone concentration is different by individual even if they have the same testes in size and tubule diameter. However, the time of capture and time until sample collections were quite varied per sample. It is known that the serum concentration changes with progress of time after sampling in some steroid hormones, ${ }^{16,17}$ but there are no data concerning whether testosterone concentration is influenced by the progress of time in cetaceans. Since captured individuals have potentially received considerable stress, it is necessary to examine this effect on testosterone levels.

Acknowledgments We thank Hidehiro Kato and Toshiya Kishiro of the Large Cetacean Section, National Research Institute of Far Seas Fisheries for providing us the opportunity to conduct the present study. We also thank Eiji Yoshida, Tetsuya Shimokawa, the Taiji Fishery Cooperative Union, the crew of the whaling ships Katsumaru, Sumitomomaru 
No. 31 and Seiwamaru and the Dolphin Hunting Team at Taiji Isano Kumiai for their kind cooperation in sample collection. Kathleen M. Dudzinski of Mie University corrected English.

\section{References}

1) I. Iida: Spermatozoon of mammal, Gakusousha, Tokyo 1972, $422 \mathrm{p}$. (in Japanese).

2) G. Desportes and A. Lacroix: Preliminary study of the male reproductive cycle in the pilot whale Globicephala melaena, off the Faroe Islands, using testes examinations and testosterone assay, Working paper submitted to the 39th IWC Scientitic Committee, May, 1987, p. 15.

3) M. Yoshioka: Endocrinological studies on cetacean reproduction. Ph.D. thesis, the University of Tokyo 1991, 130p. (in Japanese).

4) J. M. Kjeld, J. Sigurjonsson, and A. Arnason: Sex hormone concentrations in blood serum from the North Atlantic fin whale Balaenoptera physalus. J. Endocrinol., 134, 405-413 (1992).

5) R. J. Harrison and S. H. Ridgway: Gonadal activity in some bottlenose dolphins Tursiops truncatus. J. Zool., London, 162, 355366 (1971).

6) R, S. Wells: Reproductive behavior and hormonal correlates in Hawaiian spinner dolphins Stenella longirostris. Rep. int. What. Commn., Special issue 6, 465-472 (1984).

7) J. P. Schroeder and K. V. Keller: Seasonality of testosterone and sperm density in Tursiops truncatus. J. Exp. Zool., 249, 316-326 (1989).

8) T. Kasuya and H. Marsh: Life history and reproductive biology of the short-finned pilot whale Globicephala macrorhynchus off Pacific coast of Japan. Rep. int. Whal. Commn., Special issue 6, 259-310 (1984),

9) K. Asahina, A. Kambegawa, and T. Higashi: Development of a microtiter plate enzyme-linked immunosorbent assay for $17 \alpha, 20 \beta$ 21-trihydroxy-4-pregnen-3-one, a teleost gonadal steroid. Fisheries Sci., 61, 491-494 (1995).

10) M. Yoshioka, T. Okumura, K. Aida, and Y. Fujise: A proposed technique for quantifying muscle progesterone content in minke whales Balaenoptera acutorostrata. Can. J. Zool., 72, 368-370 (1994).

11) G. Desportes, M. Saboureau, and A. Lacroix: Growth-related changes in testicular mass and plasma testosterone concentration in long-finned pilot whale Globicephala melaena. J. Reprod. Fert., 102, 245-252 (1994).

12) M. Kobayashi, K, Aida, and I. Hanyu: Gonadotropin surge during spawning in male goldfish. Gen. Comp. Endocrinol., 62, 70-79 (1986).

13) E. Katsumata, T. Tobayama, M. Yoshioka, and K. Aida: Seasonal changes of serum testosterone concentration in captive male bottlenose dolphin Tursiops truncatus. Jap. J. Assoc. Zool Aqua., 35, 73-78 (1994) (in Japanese).

14) M. E. Harris and A. Bartke: Androgen levels in testis fiuid during sexual development. Experientia, 37, 426-427 (1981).

15) T. Kasuya, H. Marsh, and A. Amino: Non-reproductive mating in short-finned pilot whales. Rep. int. Whal. Commn., Special issue 14, 425-437 (1993).

16) B. S. Wiseman, D. J. Vincent, P. J. Thomford, N. S. Scheffrahn, G. F. Sargent, and D. J. Kesler: Changes in porcine, ovine, bovine and equine blood progesterone concentrations between collection and centrifugation. Anim. Reprod. Sci., 5, 157-165 (1982/1983).

17) T. J. Reimers, J. P. McCann, and R. G. Cowan: Effects of storage times and temperatures on $\mathrm{T}_{3}, \mathrm{~T}_{4}, \mathrm{LH}$, prolactin, insulin, cortisol and progesterone concentrations in blood samples from cows. $J$. Anim. Sci., 57, 683-691 (1983). 